http://dx.doi.org/10.18778/1429-3730.38.03

Waldemar Ryszard Kozłowski*

\title{
PLANOWANIE INWESTYCJI INFRASTRUKTURALNYCH W KONTEKŚCIE KSZTALTOWANIA ZRÓWNOWAŻONEGO ROZWOJU
}

\author{
PLANNING INFRASTRUCTURAL INVESTMENTS \\ IN THE CONTEXT OF SUSTAINABLE DEVELOPMENT
}

\begin{abstract}
The development of appropriate infrastructure is an essential element of the socio-economic development of a country, region or municipality. The state of Polish infrastructure is still far from satisfactory, which constitutes a barrier to rapid economic growth and social development. Technological challenges and ever-growing social expectations are forcing policy-makers to more carefully plan and implement infrastructure projects. Currently the doctrine concerning the planning and implementation of infrastructure investments is undergoing change, marked by a transition from quantitative to qualitative approaches.

The aim of this article is to present an infrastructure investment planning model based on sustainable development indicators which would adequately and appropriately measure the three major dimensions (economic, social and environmental) of a planned investment. The frame indicator model involves three levels of analysis. The first level refers to a set of partial indicators selected from the database of the indicators defined in the SDI model. The second level of indicators refers to the selection of evaluation indicators: the value, efficiency, effectiveness and quality of a given infrastructure investment. The third level of indicators based on identifying a synthetic index for evaluating an infrastructure investment project.

The model developed and presented in this article will enable decision-makers to make a comprehensive assessment of planned infrastructure investments, which allows them to choose the best projects in terms of the socio-economic development of a given area.
\end{abstract}

Key words: investment in infrastructure, the indicator model, sustainable development

JEL classification: Q01

\section{Wprowadzenie}

Rozwój infrastruktury stanowi niezbędny element rozwoju gospodarczo-społecznego kraju, regionu czy gminy. Według Paryska „rozwój społeczno-gospodarczy to proces pozytywnych przemian wzrostu ilościowego i zmian

\footnotetext{
* Dr, Uniwersytet Warmińsko-Mazurski w Olsztynie, Wydział Nauk Ekonomicznych, Katedra Ekonomiki Przestrzennej i Środowiskowej.
} 
jakościowych" (Parysek 1997:13). Stan polskiej infrastruktury jest wciąż dalece niezadowalający, co staje się barierą na drodze szybkiego wzrostu gospodarczego i społecznego (Janowska 2002:35). Wyzwania technologiczne oraz stale rosnące oczekiwania społeczne wymuszają na decydentach bardziej rozważne planowanie i realizowanie inwestycji infrastrukturalnych. Obecnie ulega również zmianie doktryna infrastrukturalna $\mathrm{w}$ zakresie planowania i realizacji inwestycji infrastrukturalnej poprzez przejście z podejścia ilościowego na jakościowy. Dlatego istotnym wyzwaniem dla samorządów lokalnych jest obecnie efektywne planowanie inwestycji infrastrukturalnych, gdzie efektywność powinna wynikać z uwzględnienia trzech podstawowych wymiarów lokalnych tj. gospodarczego, społecznego oraz środowiskowego.

Inwestycje w infrastrukturę powinny obecnie pełnić jak najszersze funkcje w rozwoju lokalnym zarówno gospodarczym jak i społecznym (Kozłowski 2012: 39). Dzisiaj wybudowanie infrastruktury nie stanowi problemu jeśli chodzi o środki kapitałowe, ale zachodzi konieczność oceny czy i jakie efekty społeczne $\mathrm{i}$ środowiskowe będą uzyskane $\mathrm{w}$ wyniku realizacji inwestycji ${ }^{1}$. Prawidłowo rozwinięta i funkcjonująca infrastruktura stwarza podstawę do rozwoju lokalnego obszaru gospodarczego i społecznego przy uwzględnieniu zasobów środowiskowych. Można zatem powiedzieć, iż rozbudowa infrastruktury stanowi pewnego rodzaju zależności, które mogą sprzyjać rozwojowi gospodarczo-społecznemu, bądź go ograniczać. Zależności te są ważną siłą napędową gminy tworząc zjawisko synergii i decydują o jakości usług infrastrukturalnych.

Istotną kwestią przy planowaniu inwestycji infrastrukturalnych jest uwzględnienie wskaźników zrównoważonego rozwoju, do realizacji którego należy dążyć prowadząc długo falową politykę rozwoju lokalnego. Zasady zrównoważonego rozwoju stały się jedną z podstawowych konstytucyjnych zasad ustroju państwa polskiego ${ }^{2}$. Wdrażanie koncepcji rozwoju zrównoważonego w aspekcie planowania i realizacji inwestycji infrastrukturalnych a także monitorowanie ich realizacji wymaga określenia mierników służących ocenie efektów, do których się przyczyniły. Powiązanie koncepcji rozwoju z efektami uzyskanymi z inwestycji ma charakter wzajemny (Gerwin 2008: 24-25).

Celem artykułu jest przedstawienie modelu planowania inwestycji infrastrukturalnych w oparciu o wskaźniki zrównoważonego rozwoju³. Wskaźniki zo-

${ }^{1}$ Szerzej na temat metod pomiaru efektów inwestycji infrastrukturalnych w gminie piszą: T. Kamińska 1999, A. Drobiniak 2002.

${ }^{2}$ Zgodnie z art. 5 Konstytucji RP: ,Rzeczpospolita Polska strzeże niepodległości i nienaruszalności swojego terytorium, zapewnia wolność i prawa człowieka i obywatela oraz bezpieczeństwo obywateli, strzeże dziedzictwa narodowego oraz zapewnia ochronę środowiska, kierując się zasadą zrównoważonego rozwoju".

${ }^{3}$ Uniwersalny zestaw Wskaźników Zrównoważonego Rozwoju (SDI) zdefiniowany został przez KE i służy do monitorowania realizacji celów Strategii Zrównoważonego Rozwoju Unii Europejskiej (EU Sustainable Development Strategy) Eurostat 2012. 
stały opracowane przez Autora w oparciu o bazę wskaźników zrównoważonego rozwoju oraz własne przemyślenia. Wskaźniki zrównoważonego rozwoju z jednej strony są nośnikami koncepcji rozwoju, a z drugiej podkreślają możliwości, które wynikają z ich praktycznego zastosowania, pozwalającego na rzetelną ocenę istniejącego stanu, a także prognozę efektów ekonomicznych społecznych i ekologicznych. Metoda badawczą zastosowaną w opracowaniu jest metoda projektowa oparta na opracowaniu modelu planowania inwestycji infrastrukturalnych.

\section{Model planowania inwestycji infrastrukturalnych}

Model planowania inwestycji infrastrukturalnych oparty został o wskaźniki zdefiniowane na 3 poziomach analitycznych. Poziom pierwszy to wskaźniki cząstkowe skumulowane w takich grupach wskaźników jak: ilościowo-wartościowe, jakościowe, efektywności cenowo-kosztowej, skuteczności. Drugi poziom analityczny odnosi się do wybranych wskaźników ładu społeczno-gospodarczego skumulowanych w 3 grupach: ekonomicznych, społecznym, oraz środowiskowym. Trzeci poziom modelu stanowi syntetyczny wskaźnik oceny rozwoju gospodarczo-społecznego danej jednostki samorządowej.

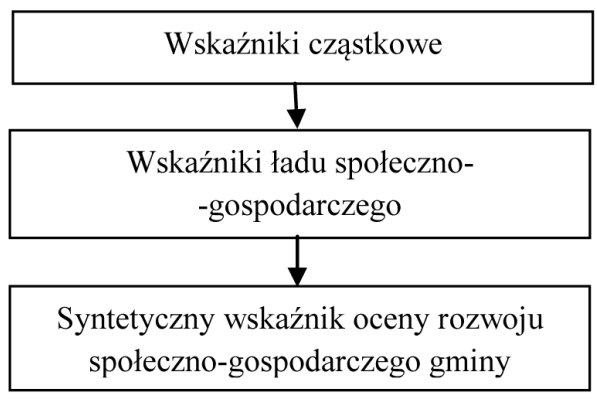

Rys. 1. Schematyczne ujęcie grup wskaźników w modelu planowania inwestycji infrastrukturalnych

Źródto: opracowanie własne.

Model zakłada, iż planowanie inwestycji infrastrukturalnych powinno odbywać się przez pryzmat trzech poziomów analitycznych począwszy od wskaźników cząstkowych odnoszących się głownie do pomiaru efektywności ekonomicznej poprzez drugi poziom odnoszący się do rozwoju zrównoważonego a skończywszy na skumulowanym wskaźniku mierzącym efekty w postaci rozwoju społeczno-gospodarczego uzyskanego dzięki inwestycjom. 


\section{Wskaźniki cząstkowe w modelu planowania inwestycji infrastrukturalnych}

Wskaźniki cząstkowe stanowią podstawę przy planowaniu inwestycji infrastrukturalnych, określają ile i za ile będziemy realizować inwestycje i jak to się ma do stanu obecnego. Pierwszy poziom analityczny powinien odpowiedzieć na pytanie jaka jest opłacalność i efektywność ekonomiczno-społeczna. Wskaźniki cząstkowe powinny zostać dobrane w taki sposób aby:

- były ściśle skorelowane z celami inwestycji infrastrukturalnych,

- były przydatne dla praktyków a w szczególności władz samorządowych które decydują o strategii inwestycyjnej,

- posiadać jasną konstrukcję, łatwą do weryfikacji w zakresie dostępności danych,

- obejmować zdefiniowany zakres czasowy i przestrzenny,

- posiadać możliwość szybkiego uaktualnienia danych.

Grupy wskaźników cząstkowych dotyczą efektywności cenowo-kosztowej, ilości i wartości, skuteczności oraz jakości (rys. 2).

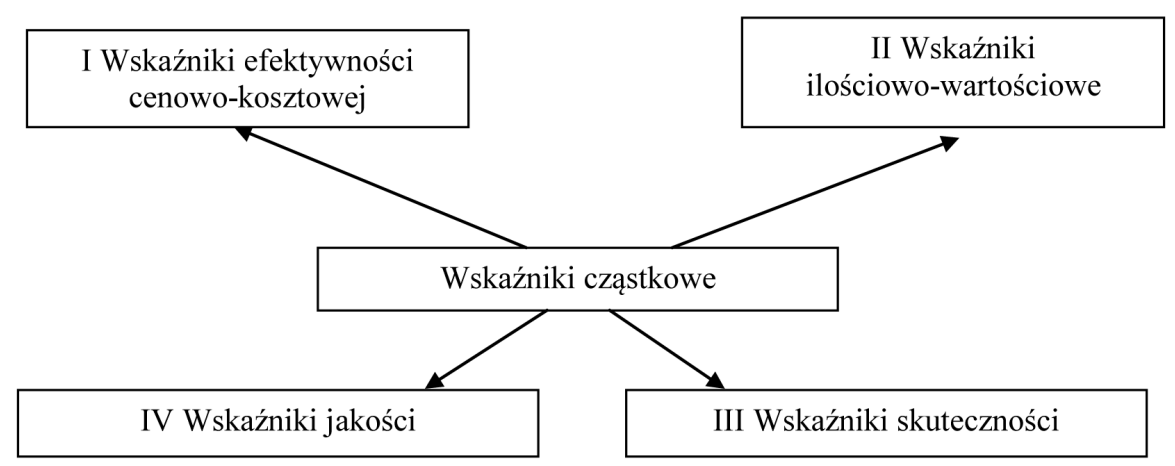

Rys. 2. Grupy wskaźników cząstkowych

Źródto: opracowanie własne.

Wskaźniki efektywności cenowo-kosztowej dotyczą wzrostu spadku cen za usługi infrastrukturalne oraz spadku lub wzrostu kosztów. Wskaźniki informują nas, jakie ceny i koszty zostaną osiagnięte po realizacji inwestycji. Powinny stanowić jedną z istotnych przesłanek inwestycyjnych. Szczegółowe formuły wskaźników zawarte zostały w tabeli 1.

Wskaźniki ilościowo-wartościowe odnoszą się do danych ilościowo-wartościowych w miernikach liczbowych i naturalnych. Stanowią punkt odniesienia odnośnie zainwestowanego kapitału i uzyskanych efektów ilościowych. Punktem odniesienia tej grupy wskaźników jest stan przed inwestycją (tabela 1).

Wskaźniki skuteczności dotyczą pomiaru efektów ekonomiczno-społecznych jakie zostaną uzyskane dzięki realizacji inwestycji infrastrukturalnej. Sens 
rozbudowy infrastruktury związany jest oddziaływaniem na rozwój gospodarczo-społeczny danego regionu. Wskaźniki w zależności od rodzaju prognozują jaki wpływ na rynek pracy, podmioty gospodarcze i jakość życia będzie miała realizacja danego rodzaju infrastruktury.

Wskaźniki jakościowe dotyczą oceny jakościowej działań inwestycyjnych w gminie w oparciu o pomiar metoda kwestionariuszową przez społeczeństwo oraz podmioty funkcjonujące na rynku. Szczegółowe formuły wskaźników cząstkowych zawiera tabela 1.

Tabela 1. Wskaźniki cząstkowe inwestycji infrastruktury technicznej

\begin{tabular}{|c|c|c|c|}
\hline Lp. & Wskaźnik & Formuła/narzędzie pomiaru & Punkt odniesienia \\
\hline \multicolumn{4}{|c|}{ I Wskaźniki efektywności cenowo- kosztowej } \\
\hline $\mathrm{C} 1$ & $\begin{array}{l}\text { Wzrost/spadek cen usługi } \\
\mathrm{z} \text { infrastruktury }\end{array}$ & $\begin{array}{l}\text { Cena na jednostkę usługi / kwh, } \mathrm{dm}^{3} \text {, } \\
\mathrm{mb}, \mathrm{GJ}, \mathrm{kg} \text {, tona itp./ zł }\end{array}$ & $\begin{array}{l}\text { Ceny usług przed inwe- } \\
\text { stycją }\end{array}$ \\
\hline K1 & $\begin{array}{l}\text { Spadek kosztów usług } \\
\text { komunalnych przejazdu }\end{array}$ & $\begin{array}{l}\text { Cena usługi komunalnej / } \mathrm{m}^{2} \text { lub } \\
\text { mieszkańca }\end{array}$ & $\begin{array}{l}\text { Koszt usług przed inwe- } \\
\text { stycją }\end{array}$ \\
\hline K2 & $\begin{array}{l}\text { Koszt budowy infrastruktury } \\
\mathrm{m} / \mathrm{b}, \mathrm{km}\end{array}$ & $\begin{array}{l}\text { Wartość inwestycji / ilość jednostek } \\
\text { naturalnych }\end{array}$ & $\begin{array}{l}\text { Średnia cena budowy } \\
\text { infrastruktury w europie, } \\
\text { kraju, regionie, gminie. }\end{array}$ \\
\hline K3 & $\begin{array}{l}\text { Spadek kosztów eksploata- } \\
\text { cji infrastruktury }\end{array}$ & $\begin{array}{l}\text { Spadek kosztów operacyjnych utrzy- } \\
\text { mania infrastruktury / rok }\end{array}$ & Lata ubiegłe \\
\hline \multicolumn{4}{|c|}{ II Wskaźniki ilościowo-wartościowe } \\
\hline W1 & $\begin{array}{l}\text { Ilość wybudowanej infra- } \\
\text { struktury }\end{array}$ & $\begin{array}{l}\text { Ilość infrastruktury / liczba miesz- } \\
\text { kańców }\end{array}$ & $\begin{array}{l}\text { Ilość infrastruktury na } \\
\text { mieszkańca w latach } \\
\text { przed inwestycją }\end{array}$ \\
\hline W2 & $\begin{array}{l}\text { Ilość zmodernizowanej } \\
\text { infrastruktury }\end{array}$ & $\begin{array}{l}\text { Ilość infrastruktury / liczba miesz- } \\
\text { kańców }\end{array}$ & $\begin{array}{l}\text { Ilość infrastruktury na } \\
\text { mieszkańca w latach } \\
\text { przed inwestycją }\end{array}$ \\
\hline W3 & Ilość liczby użytkowników & $\begin{array}{l}\text { Liczba użytkowników / ilość infra- } \\
\text { struktury }\end{array}$ & Stan przed inwestycją \\
\hline W4 & $\begin{array}{l}\text { Wartość inwestycji infra- } \\
\text { strukturalnych }\end{array}$ & $\begin{array}{l}\text { Liczba użytkowników / wartość } \\
\text { inwestycji infrastrukturalnych }\end{array}$ & Stan przed inwestycją \\
\hline \multicolumn{4}{|c|}{ III Wskaźniki skuteczności } \\
\hline & Wzrost ilości miejsc pracy & $\begin{array}{l}\text { Ilość nowych miejsc pracy / po- } \\
\text { przedni stanu miejsc pracy }\end{array}$ & Stan przed inwestycją \\
\hline & $\begin{array}{l}\text { Wzrost liczby przedsię- } \\
\text { biorstw }\end{array}$ & $\begin{array}{l}\text { Ilość nowych przedsiębiorstw / po- } \\
\text { przedni stanu ilości przedsiębiorstw }\end{array}$ & Stan przed inwestycją \\
\hline & $\begin{array}{l}\text { Wzrost dochodów gminy } \\
\text { z tytułu podatków i opłat }\end{array}$ & $\begin{array}{l}\text { Dochody gminy z tytułu podatków, } \\
\text { opłat infrastrukturalnych / dochody } \\
\text { w okresie poprzednim }\end{array}$ & Okres poprzedni \\
\hline & $\begin{array}{l}\text { Poprawa zdrowotności } \\
\text { mieszkańców }\end{array}$ & $\begin{array}{l}\text { Ilość zachorowań z tytułu źle funk- } \\
\text { cjonującej infrastruktury / ilość za- } \\
\text { chorowań w okresie poprzednim }\end{array}$ & Okres poprzedni \\
\hline & $\begin{array}{l}\text { Poprawa dostępności } \\
\text { komunikacyjnej gminy }\end{array}$ & $\begin{array}{l}\text { Szybkość przejazdu przed inwestycja } \\
\text { / szybkość przejazdu po inwestycji }\end{array}$ & Okres poprzedni \\
\hline
\end{tabular}


Tabela 1. Wskaźniki cząstkowe inwestycji infrastruktury technicznej cd.

\begin{tabular}{|l|l|l|l|}
\hline \multicolumn{2}{|c|}{ Wp. } & \multicolumn{1}{c|}{ Formula/narzędzie pomiaru } & Punkt odniesienia \\
\hline \multicolumn{3}{|c|}{ IV Wskaźniki jakościowe } \\
\hline & $\begin{array}{l}\text { Wzrost zadowolenia miesz- } \\
\text { kańców, }\end{array}$ & $\begin{array}{l}\text { Poziom zadowolenia po inwestycji / } \\
\text { poziom zadowolenia przed inwestycją }\end{array}$ & Kwestionariusz Serquala \\
\hline & $\begin{array}{l}\text { Wzrost atrakcyjności } \\
\text { inwestycyjnej gminy }\end{array}$ & $\begin{array}{l}\text { Ilość inwestycji / poziom zadowole- } \\
\text { nia inwestorów }\end{array}$ & Kwestionariusz Serquala \\
\hline & Dostosowanie do przepisów & Ilość inwestycji / ilość kar & Dane statystyczne \\
\hline & $\begin{array}{l}\text { Poprawa środowiska } \\
\text { naturalnego }\end{array}$ & $\begin{array}{l}\text { Ilość inwestycji / poprawa jakości } \\
\text { środowiska naturalnego }\end{array}$ & $\begin{array}{l}\text { Mierniki naturalne/ dane } \\
\text { statystyczne }\end{array}$ \\
\hline
\end{tabular}

Źródło: opracowanie własne.

Wskaźniki cząstkowe umożliwiają zaplanowanie spodziewanych efektów uzyskanych z inwestycji infrastrukturalnych gdzie punktem odniesienia będzie stan przed inwestycją. Powinny być zastosowane przy planowaniu strategii inwestycyjnych np. przy wieloletnich planach inwestycyjnych (WPI), czy też w zintegrowanych inwestycjach terytorialnych (ZIT). Dzięki wskaźnikom możliwe jest obiektywne zdefiniowanie potencjalnych efektów przed realizacją inwestycji.

\section{Wskaźniki ladu społeczno-gospodarczego w modelu planowania inwestycji infrastrukturalnych}

Wskaźniki ładu społeczno-gospodarczego stanowią uproszczenie analityczne wskaźników cząstkowych i służą do oceny inwestycji infrastrukturalnych z perspektywy zrównoważonego rozwoju. Wskaźniki są niezwykle użyteczne przy opracowaniu i aktualizacji strategii rozwojowych jednostek samorządu, w tym strategii sektorowych, oraz studiów wykonalności do projektów finansowanych ze środków Unii Europejskiej. Ich zmiana w czasie, w zestawieniu ze zmianami $\mathrm{w}$ innych podobnych samorząach pozwala na monitoring procesów i programów rozwojowych realizowanych w danej jednostce samorządu.

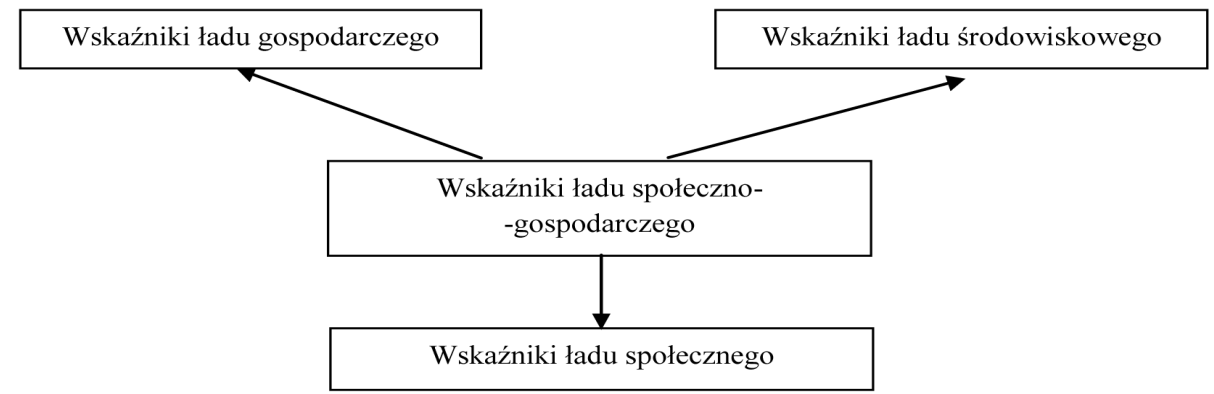

Rys. 3. Wskaźniki ladu społeczno-gospodarczego

Źródto: opracowanie wtasne. 
Dla potrzeb opracowania w grupie wskaźników gospodarczych zdefiniowano następujące wskaźniki:

G1 - nakłady inwestycyjne na infrastrukturę gospodarczą zł/mieszkaniec,

G2 - dochody własne gminy zł/mieszkańca,

G3 - dynamika wzrostu liczby nowych przedsiębiorstw w gminie \%,

G4 - dynamika wzrostu zatrudnienia w gminie \%.

W grupie wskaźników społecznych zdefiniowano wskaźniki:

S1 - wydatki majątkowe na oświatę w przeliczeniu zł/mieszkańca,

S2 - wydatki majątkowe na sport i rekreację w przeliczeniu zł/mieszkańca,

S3 - wydatki majątkowe na kulturę w przeliczeniu zł/mieszkańca,

S4 - ogólne saldo migracji na 1000 ludności \%.

W grupie wskaźników środowiskowych zdefiniowano wskaźniki:

Ś1 - wydatki na infrastrukturę ochrony środowiska zł/ mieszkańca,

Ś2 - dynamika przyrostu liczby ludności korzystającej z sieci kanalizacyjnej \%,

Ś3 - dynamika liczby ludności korzystającej z oczyszczalni ścieków \%,

Ś4 - ilość odpadów zebranych w ciagu roku kg/mieszkańca,

Analiza wskaźników w obszarze zrównoważonego rozwoju umożliwia planowanie i monitorowanie w jakim zakresie inwestycje infrastrukturalne wpływają na rozwój zrównoważony. Wskaźniki zrównoważonego rozwoju mogą ulegać modyfikacjom w zależności od rodzaju planowanej infrastruktury technicznej. Dobór wskaźników powinien być oparty na dwóch istotnych przesłankach: wyborze najważniejszych wskaźników danego ładu, oraz hipotetycznie założonym związku przyczynowo-skutkowym między inwestycją infrastrukturalną a rozwojem gminy.

\section{Syntetyczny wskaźnik oceny rozwoju społeczno-gospodarczego}

W celu uporządkowania liniowego gmin ze względu na poziom rozwoju społeczno-gospodarczego wykorzystano wskaźnik syntetyczny Perkala będącego sumą wartości standaryzowanych wartości cząstkowych, tworzonego w oparciu o wzór (Runge, 2007: 214).

$$
W P=\frac{\sum_{j=1}^{p} y_{i j}}{p}
$$

gdzie:

$W P$ - wskaźnik syntetyczny Perkala,

$p$ - liczba uwzględnionych cech,

$y_{i j}$-standaryzowana wartość $j$-tej cechy dla $i$-tego obiektu.

Dzięki wykorzystaniu wskaźnika Perkala można uzyskać ogólny obraz przestrzennego zróżnicowania gmin powiatu olsztyńskiego pod względem rozwoju społeczno-gospodarczego. Na podstawie uzyskanych wartości syntetycznego miernika Perkala przeprowadzono klasyfikację gmin. Podstawą uzyskania klas są 
przedziały, jakie przyjmuje wskaźnik w oparciu o średnią arytmetyczną i odchylenie standardowe (Szymla 2000: 23):

I $W P>\bar{x}+\mathrm{s}$ xbardzo dobry,

II $\bar{x}<W P<\bar{x}+$ s dobry,

III $\bar{x}-\mathrm{s}<W P<\bar{x}$ dostateczny,

IV $W P<\bar{x}-$ s niedostateczny. gdzie:

$W P$ - wskaźnik Perkala,

$\bar{x}$ - średnia arytmetyczna,

$\mathrm{s}$ - odchylenie standardowe.

Zastosowanie wskaźnika syntetycznego wymagało w pierwszej kolejności standaryzacji wartości wskaźników opisujących natężenie poszczególnych cech w gminach powiatu.

\section{Wyniki badań własnych}

\section{Wydatki inwestycyjne gmin powiatu olsztyńskiego}

Założenia modelu wykorzystano do analizy obecnej sytuacji w gminach powiatu olsztyńskiego. Na pierwszym etapie przeanalizowano wydatki inwestycyjne w gminach powiatu olsztyńskiego w podziale na: gospodarkę mieszkaniową, ochronę środowiska, gospodarkę komunalną, oraz infrastrukturę drogową (tabela 2).

Tabela 2. Wydatki inwestycyjne na infrastrukturę gospodarczą w gminach powiatu olsztyńskiego za lata 2007-2012

\begin{tabular}{|r|l|r|r|r|r|r|}
\hline & & \multicolumn{5}{|c|}{ Wydatki inwestycyjne na infrastrukturę gospodarczą } \\
\cline { 3 - 7 } Lp. & Gmina & $\begin{array}{c}\text { Gospodarka } \\
\text { mieszkaniowa }\end{array}$ & $\begin{array}{c}\text { Ochrona } \\
\text { środowiska } \\
\text { rolnictwo }\end{array}$ & $\begin{array}{c}\text { Gospodarka } \\
\text { komunalna }\end{array}$ & $\begin{array}{c}\text { Infrastruktura } \\
\text { drogowa }\end{array}$ & \multirow{2}{|c|}{$\Sigma$} \\
\hline $\mathbf{1}$ & Stawiguda & 1013633 & 10766048 & 898056 & 18353516 & 31031253 \\
\hline $\mathbf{2}$ & Świątki & 813930 & 1210163 & 2062791 & 89608 & 4176492 \\
\hline $\mathbf{3}$ & Purda & 2544104 & 6685589 & 3759159 & 451694 & 13440546 \\
\hline $\mathbf{4}$ & Olsztynek & 4180018 & 7337191 & 16607943 & 982375 & 29107527 \\
\hline $\mathbf{5}$ & Kolno & 94380 & 5510942 & 77188 & 0 & 5682510 \\
\hline $\mathbf{6}$ & Jonkowo & 122412 & 0 & 18673208 & 1493464 & 20289084 \\
\hline $\mathbf{7}$ & Jeziorany & 2140020 & 1899492 & 7181164 & 10325906 & 21546582 \\
\hline $\mathbf{8}$ & Gietrzwałd & 1385242 & 6401269 & 423065 & 3590622 & 11800198 \\
\hline $\mathbf{9}$ & Dywity & 552684 & 6077857 & 1024606 & 17501783 & 25156930 \\
\hline $\mathbf{1 0}$ & Dobre Miasto & 2729153 & 1023717 & 116931 & 8601138 & 12470939 \\
\hline $\mathbf{1 1}$ & Biskupiec & 2286645 & 12212531 & 15945153 & 30356416 & 60800745 \\
\hline $\mathbf{1 2}$ & Barczewo & 1922753 & 10972353 & 12449167 & 16734950 & 42079223 \\
\hline & Razem & 19784974 & 70097152 & 79218431 & 110481472 & 279582029 \\
\hline
\end{tabular}

Źródto: opracowanie własne na podstawie danych BDR $2013 \mathrm{r}$. 
Inwestycje infrastrukturalne stanowią ogółem 54\% wszystkich wydatków inwestycyjnych poniesionych przez gminy powiatu olsztyńskiego. Wydatki są podstawą rozwoju gospodarczego, wpływają na lokalną atrakcyjność inwestycyjną oraz jakość życia społeczności lokalnej. Najwięcej środków finansowych na infrastrukturę wydatkowano w ostatnich pięciu latach na inwestycje infrastruktury drogowej $110,5 \mathrm{mln}$ zł. Najmniej natomiast na infrastrukturę mieszkaniową 19,78 mln zł. Liderem pod względem wydatków infrastrukturalnych jest gmina Biskupiec ponad $60 \mathrm{mln}$.

\section{Przeslanki inwestycyjne w zakresie planowania infrastruktury badanych gmin}

Badania przeprowadzono metodą ankietową w gminach powiatu olsztyńskiego. Badania ankietowe wskazują, iż podstawową przesłanką skłaniającą samorządy do realizacji inwestycji infrastrukturalnych jest możliwość skorzystania z bezzwrotnych środków unijnych $(98 \%$ badanych wskazało tę przesłankę jako priorytet). Drugą i trzecią w kolejności jest przesłanka związana z koniecznością budowy ( $82 \%$ ) oraz modernizacji infrastruktury (75\%). Przesłanką o najmniejszej wadze decyzyjnej są działania wywołane presją środowiskową i społeczną w danej gminie. Szczegółowe wyniki badań przedstawia tabela 3.

Tabela 3. Przesłanki realizacji inwestycji infrastrukturalnych $w$ gminach powiatu olsztyńskiego

\begin{tabular}{|c|l|l|l|c|c|}
\hline Lp. & \multicolumn{1}{|c|}{ Przesłanka glówna } & \multicolumn{1}{|c|}{$\begin{array}{c}\text { Wskaźniki } \\
\text { cząstkowe }\end{array}$} & $\begin{array}{c}\text { Wskaźniki } \\
\text { ladów }\end{array}$ & $\begin{array}{c}\text { Ważność przesłan- } \\
\text { ki dla samorządów } \\
\text { od 0,1 do 1 }\end{array}$ & $\begin{array}{c}\text { Ilość } \\
\text { gmin }\end{array}$ \\
\hline 1 & Środki europejskie & $\begin{array}{l}\text { ilościowo-warto- } \\
\text { ściowe }\end{array}$ & gospodarczy & $\mathbf{0 , 9 8}$ & $\mathbf{1 2}$ \\
\hline 2. & $\begin{array}{l}\text { Koniecznosć rozbudo- } \\
\text { wy infrastruktury }\end{array}$ & $\begin{array}{l}\text { ilościowo-warto- } \\
\text { ściowe }\end{array}$ & gospodarczy & $\mathbf{0 , 8 2}$ & $\mathbf{1 0}$ \\
\hline 3. & $\begin{array}{l}\text { Konieczność moderni- } \\
\text { zacji posiadanej infra- } \\
\text { struktury }\end{array}$ & $\begin{array}{l}\text { ilościowo-warto- } \\
\text { ściowe }\end{array}$ & gospodarczy & $\mathbf{0 , 7 5}$ & 7 \\
\hline 4. & $\begin{array}{l}\text { Dostosowanie do prze- } \\
\text { pisów prawnych }\end{array}$ & jakości & $\begin{array}{l}\text { środowisko- } \\
\text { wy }\end{array}$ & $\mathbf{0 , 7 0}$ & $\mathbf{6}$ \\
\hline 5. & $\begin{array}{l}\text { Działania wynikające } \\
\text { z przyjętej strategii }\end{array}$ & skuteczności & gospodarczy & $\mathbf{0 , 5 0}$ & $\mathbf{5}$ \\
\hline 6. & Presja społeczna & jakości & społeczny & $\mathbf{0 , 3 5}$ & $\mathbf{4}$ \\
\hline 7. & Presja środowiskowa & jakości & środowiskowy & $\mathbf{0 , 2 5}$ & $\mathbf{7}$ \\
\hline
\end{tabular}

Źródto: opracowanie własne.

Dominujący charakter przesłanki związanej z możliwością pozyskania bezzwrotnych środków unijnych może mieć wpływ na nadpodaż w budowie infrastruktury jak również świadczy o słabej sile oddziaływania czynników społeczno-środowiskowych. Taka sytuacja może powodować również wzrost 
kosztów utrzymania infrastruktury, które to zostaną przeniesione na społeczność lokalną.

W ramach przesłanek inwestycyjnych dominująca grupę wskaźników cząstkowych branych pod uwagę przy planowaniu inwestycji infrastrukturalnych były wskaźniki ilościowo-wartościowe. Całkowicie pominięte były wskaźniki efektywności ceno-kosztowej oraz skuteczności, co świadczy o braku zainteresowania decydentów kwestiami ładu społecznego. Efekt zrealizowanych inwestycji zdefiniowany został za pomocą skumulowanego wskaźnika Perkala (1), dzięki czemu można zmierzyć skuteczność prowadzonej polityki inwestycyjnej na terenie gminy. Szczegółowe wyniki analizy przedstawia tabela 4.

Tabela 4. Poziom rozwoju gmin powiatu olsztyńskiego

\begin{tabular}{|l|l|l|l|l|}
\hline $\begin{array}{c}\text { Klasa 1 } \\
\text { Bardzo wysoki } \\
\text { poziom rozwoju } \\
\text { WP }[\mathbf{1 , 2 5 ; 0 , 5 0 ]}\end{array}$ & $\begin{array}{c}\text { Klasa 2 } \\
\text { Wysoki poziom } \\
\text { rozwoju } \\
\text { WP }[\mathbf{0 , 4 9 ; 0 , 0 8}]\end{array}$ & $\begin{array}{c}\text { Klasa 3 } \\
\text { Przeciętny poziom } \\
\text { rozwoju } \\
\text { WP }[\mathbf{0 , 0 7 ; - 0 , 1 0 ]}\end{array}$ & $\begin{array}{c}\text { Klasa 4 } \\
\text { Niski poziom } \\
\text { rozwoju } \\
\text { WP }[-\mathbf{0 , 1 1 ; - 0 , 5 0 ]}\end{array}$ & $\begin{array}{c}\text { Klasa 5 } \\
\text { Bardzo niski } \\
\text { poziom rozwoju } \\
\text { WP }[-\mathbf{0 , 5 1 ; - 0 , 7 0 ]}\end{array}$ \\
\hline Dywity & Dobre Miasto & Olsztynek & Purda & Kolno \\
\hline Stawiguda & Barczewo & Gietrzwałd & Jeziorany & Świątki \\
\hline & & Jonkowo & & \\
\hline & & Biskupiec & & \\
\hline
\end{tabular}

Źródto: opracowanie własne.

Na bazie przeprowadzonej analizy można stwierdzić, iż największy poziom rozwoju w odniesieniu do badanych gmin zanotowały Dywity i Stawiguda. Najniższy poziom rozwoju Kolno i Świątki. Obie najbardziej rozwojowe gminy nie należą jednak do liderów jeśli chodzi o wartość wszystkich wydatków na infrastrukturę gminną. Gmina Stawiguda wydała w latach 2007-2012 $31 \mathrm{mln}$, natomiast gmina Dywity $25 \mathrm{mln}$. Oznacza to jednak, iż inwestycje zrealizowane w gminie Stawiguda i Dywity były bardziej efektywne niż w pozostałych gminach mimo niższych nakładów. Charakterystyczna cechą działalności badanych gmin był fakt dobrze zorganizowanych konsultacji społecznych i akceptacji projektów zgłaszanych przez społeczność lokalną.

\section{Podsumowanie}

Inwestycje infrastrukturalne stanowią istotny element rozwoju społeczno-gospodarczego. Dominującymi przesłankami w realizacji inwestycji infrastrukturalnych powinny być rzeczywiste potrzeby gminy oparte na wskaźnikach zrównoważonego rozwoju. Badania przeprowadzone w gminach powiatu olsztyńskiego wskazują na fakt, iż dominującą przesłanką jest pozyskanie środków unijnych, a wśród wskaźników cząstkowych dominują wskaźniki ilościowo-wartościowe. 
Gminy nie biorą pod uwagę przed realizacją inwestycji wskaźników cenowo-kosztowych i w ograniczonym wymiarze wskaźniki skuteczności, co powoduje, iż dominuje koncepcja rozwoju ładu gospodarczego.

Planowanie oparte na dominującej roli ładu gospodarczego nie gwarantuje efektywności opartej na zrównoważonym rozwoju. Dlatego też ważne z punktu widzenia infrastruktury $\mathrm{w}$ gminie jest analizowanie i prognozowanie efektów na trzech płaszczyznach tj. gospodarczym, społecznym i środowiskowym w oparciu o model wskaźnikowy.

Planowanie infrastruktury wyłącznie w odniesieniu do ładu gospodarczego może spowodować nadpodaż infrastruktury, co z kolei może spowodować wzrost kosztów jej utrzymania. Należy przy tym pamiętać, iż każda inwestycja podlega spłacie czy to w sposób bezpośredni czy pośredni przeniesiona zostanie na społeczność lokalną. Dlatego też wskazane jest lepsze uświadomienie decydentom, jakie skutki może przynieść instrumentalne podejście do inwestycji infrastrukturalnych.

Obecnie nadszedł czas przejścia od podejścia ilościowego na rzecz podejścia jakościowego w odniesieniu do planowania i realizacji inwestycji infrastrukturalnych. Obecnie jest dobry czas gdzie należałoby się zastanowić nad oceną efektywności przeprowadzonych inwestycji z punktu widzenia kosztów utrzymania jak również generowania dochodów.

\section{Bibliografia}

Drobiniak A. (2002), Zastosowanie analizy korzyści i kosztów w ocenie projektów publicznych, Katowice.

Gerwin M. (2008), Plan zrównoważonego rozwoju dla Polski, Sopot.

Janowska H. (2002), Strategie finansowania gminnych inwestycji infrastrukturalnych w Polsce, Szczecin.

Kamińska T. (1999), Makroekonomiczna ocena efektywności inwestycji infrastrukturalnych na przyktadzie transportu, Gdańsk.

Kozłowski W. (2012), Zarzqdzanie gminnymi inwestycjami infrastrukturalnymi, Warszawa.

Parysek J.J, (1997), Podstawy gospodarki lokalnej, Wydawnictwo Naukowe, Poznań.

Runge J. (2007), Metody badań w geografii społeczno-ekonomicznej, Katowice.

Szymla Z. (2000), Determinanty rozwoju regionalnego, Wrocław.

\section{Streszczenie}

Rozwój infrastruktury stanowi niezbędny element rozwoju gospodarczego i społecznego kraju, regionu czy gminy. Istotnym wyzwaniem dla samorządów lokalnych jest obecnie planowanie inwestycji infrastrukturalnych przez pryzmat trzech wymiarów tj. gospodarczego, społecznego oraz środowiskowego. Tematem artykułu jest opracowanie modelu planowania inwestycji infrastrukturalnych w oparciu o wskaźniki zrównoważonego rozwoju. Celem takiego podejścia jest pomiar trzech ważnych wymiarów (gospodarka, społeczeństwo, środowisko), związanych z planowaną inwestycją.

Słowa kluczowe: inwestycje infrastrukturalne, model wskaźnikowy, zrównoważony rozwój Numer klasyfikacji JEL: Q01 